Yu.V.Dubiei, orcid.org/0000-0003-3415-3470
Dnipro University of Technology, Dnipro, Ukraine, e-mail: yuliya.dubey@gmail.com

\title{
INTERRELATION BETWEEN HUMAN CAPITAL AND INNOVATION IN THE CONTEXT OF TECHNICAL AND TECHNOLOGICAL DEVELOPMENT OF A COUNTRY
}

Purpose. To reveal the interrelation between the economic growth of countries and the key determinants of technical and technological development.

Methodology. In the course of the study, the following general scientific methods of scientific knowledge were used: factor analysis - to highlight the key factors of economic growth; the method of logical and historical analysis - to identify the specifics of Asian countries as leaders of catch-up development; statistical methods - to establish the dependence of the rates of economic growth of countries on the quantitative and qualitative characteristics of human and physical capital.

Findings. The models of economic growth based on the use of human capital as a factor in increasing GDP are analyzed. Based on factual material on the results of economic development of countries that actively carried out reforms in the field of education in the 1990s, the absence of a direct link between investment in human capital and economic growth was proved. The prerequisites for the successful realization of the potential of human capital are highlighted, the main of which is the compliance of its qualitative characteristics with the technical and technological characteristics of physical capital. On a sample of 36 countries of the world, this dependence was proved and clusters of countries were identified according to the correspondence of indicators of human development and innovativeness of economies, as well as the structure of their production and existing development drivers. The example of China demonstrates the successful implementation of the policy of building the potential of human capital with the corresponding technological shifts based on giving the investments an innovative orientation.

Originality. The dependence of the rates of economic growth on the synchronization of the quantitative and qualitative characteristics of human and physical capital has been proved; the necessary and sufficient conditions have been substantiated for the country to enter the trajectory of sustainable technical and technological development.

Practical value. The established interrelation between the economic growth of countries and the correspondence between the quantitative and qualitative characteristics of human and physical capital makes it possible to more effectively choose the directions of the economic policy of the state in the field of technical and technological development.

Keywords: scientific and technological development, models of economic growth, human capital, innovations, GDP growth rates

Introduction. Today there is no doubt that one of the fundamental factors of socio-economic development of countries is scientific and technological progress. History shows that science and new technologies have radically changed the technical and technological basis of production and skills of labor, contributed to the deepening of the division of labor and, consequently, led to increased social welfare of those economic systems in which the implementation of scientific and technical process results took place.

This obvious interdependence between scientific and technological progress and the growth of production efficiency has become a kind of guide in the choice of factors of economic development. Focusing on the economic successes of Germany, Japan, and the Soviet Union, which, although due to various factors, demonstrated an unprecedented "leap" in building economic potential after World War II to catch up with the then most successful United States and Britain, the majority of countries chose the path of rapid modernization, trying to move along the path of industrial progress and to reproduce Western-style institutions in their economic systems. The idea of so-called "catch-up development" became widespread at that time, the authors of which proved the fundamental possibility for backward countries to reduce the gap with the advanced countries of the world in a relatively short time. In the works by P. Bauer, K.Clark, A. Hirschman, A. Lewis, G. Myrdal, R. Prebisch and a number of other researchers, to some extent, the idea that the use of new technologies, efficient energy sources, increased specialization of labor and the development of commodity and money markets can be the basis for a fairly rapid modernization (Rostow W., 1990).

Time has shown that these predictions did not come true. Of all the countries that followed the path of catching up in the second half of the twentieth century, only Hong Kong, Taiwan, Singapore and South Korea have demonstrated more or

(C) Dubiei Yu.V., 2020 less significant results in the implementation of the concept of rapid modernization. In the $21^{\text {st }}$ century, China has shown significant success in this direction, combining administrative-command and market elements of management in its socio-economic system, and achieving one of the highest rates of economic growth in the world at the same time. As for other countries, to this day they have not been able to overcome poverty, social inequality and dependence on the Western world. A natural question arises, what are the reasons for this state of affairs?

Literature review. The analysis of existing research on this issue has revealed a fairly active scientific research in this area. Thus, the issue of global uneven distribution of countries' capacity for scientific innovation is addressed in the works by M. Mormina, focuses on the need to develop and support socio-economic and political structures that contribute to knowledge creation as a means of bridging the scientific and technological gap between developed and developing countries [1]. L. Bezuidenhout actively investigates the problem of mismatch of human capital and innovation infrastructure of middle and low levels of development. In particular, the issues of insufficient provision of researchers with information and communication technologies in these countries are raised and the directions of overcoming "digital inequality" are suggested [2], as well as the weakness of the resource scientific and technical base in the context of information exchange among scientists from 13 sub-Saharan countries [3]. The relationship between the development of science, technology, education and skills of workers in the context of the study on economic growth is the main focus of the work by V. Martinez [4]. Ukrainian researchers are more concentrated on studying the experience of countries that are rapidly overcoming technological backwardness (for example, [5]).

Despite significant improvements in the field of research into the causes of uneven economic growth in view of the technical and technological component, a significant range of theoretical and practical issues is still far from being finally re- 
solved. In particular, the nature of the connection between the key factors of technical and technological development and the socio-economic consequences of their impact is not clarified; the prerequisites for the realization of the potential of science in different countries are not defined.

Purpose. The purpose of this study is to determine the relationship between economic growth and key determinants of technical and technological development.

Results. The scientists started to consider science and innovations generated by new knowledge as sources of socioeconomic development in the late $19^{\text {th }}$ - early $20^{\text {th }}$ centuries. Three world-renowned thinkers - M. Tugan-Baranovsky, M. Kondratiev and J.Schumpeter - became the founders of the theory of innovative development of the world economy. In the famous work by M. Tugan-Baranovsky "Industrial crises in modern England, their causes and close impact on people's lives" (1894) it was first shown that crises are due to the fact that in the phase of rising, the consumption of capital is faster than its formation and therefore the less capital a country has at its disposal to support its industry in the phase of rising, the sooner this rise ends (Petrograd, 1923). Thus, for the first time in the history of economic thought, the Ukrainian economist linked the unevenness of economic development with fluctuations in the amount of investment.

This idea served as a starting point in the development of the concept of long-wave oscillations by M. Kondratiev. Believing that investments are made in order to maximize profits, and machinery and technology, in their turn, increase the labor productivity, the scientist showed that in the economy periodically occur situations of mass accumulation of capital and its investment in new machinery and technology. These processes divert the economic system from equilibrium. Considering these deviations on the empirical facts of development of different countries for 100-150 years, M. Kondratiev discovered the subordination of economic development to large cycles of conjuncture with an amplitude of about 50 years, and thus he proved that they are associated with waves of technical inventions and their practical application. This, according to the scientist, "strengthens the role of new countries (those that introduce innovations) in world economic life" (N. Kondratiev, 1928).

Schumpeter J. says that technical inventions are only a potential for development. For real influence on development parameters, the figure of the businessman-innovator who overcomes inertia is of great importance, by changing a combination of manufacture factors and improving them taking into account new technical and technological knowledge, at the same time opens new opportunities for profit, and in this way creates conditions for the accelerated economic development (Schumpeter J., 1911). It is important to note that J. Schumpeter focuses not only on the factors of growth, but also on the factors that oppose innovation, linking it to the evolution of the capitalist system. In "Capitalism, Socialism and Democracy" (Schumpeter J., 1942), the scientist shows that along with the "erosion of property" in the transition to domination in large corporations, which are not prone to innovation, innovative development is gradually inhibited.

Thus, the above ideas served as a basis for identifying two key factors of development: the amount of capital and entrepreneurship, which, in fact, began to be associated with the ability of countries to overcome backwardness.

Focusing on the capital component, R. Solow demonstrated the limited economic growth that is achieved through the accumulation of capital capacity through investment (Solow, 1956). With the constant size of the labor force, capital shows a declining return, and an increase in its stock and intensity of exploitation requires an increasing share of investment in reproduction. For these reasons, economic growth is characterized by a gradual decline. This model was used by R. Solow to explain the examples of rapid growth that were characteristic of postwar Germany and Japan, where capital capacity was virtually destroyed and the economy showed very rapid growth with even a small share of investment. The small stock of capital in the presence of free labor allowed these countries to achieve much greater returns than in those where there was a high load of fixed capital and there were significant costs of resources to maintain its efficiency. By this logic, economic growth should gradually slow in all countries to a complete halt. To solve this problem, R. Solow introduces technical progress into the model as a factor that increases the possibilities of labor and, thus, eliminates the effect of declining returns. It followed that using technical progress, all countries have the same chances to achieve economic growth and thus gradually overcome inequality.

Solow's R. model, as the first concept that demonstrated the process of convergence of countries, has repeatedly been subject to empirical verification and improvement. In this regard, the most significant approaches can be considered those that, starting with R. Lucas (Lucas, 1988) and P. Romer (Romer, 1992), transformed technical progress from exogenous to endogenous factor and linked it to the quality of human capital (a detailed consideration of these concepts is presented in [6]). One such attempt is the approach of G. Menkew, D. Romer, and D. Weil, who tested R. Solow's model in 195 developing countries between 1960 and 1985. In general, the conclusions of the model were confirmed, but the impact of the share of savings and the growth rate of the working population was slightly larger than expected. The explanation for this discrepancy was made by introducing human capital into the model, which, according to researchers, compensated for the lack of physical capital. This leads to the conclusion that by investing in human capital it is possible to achieve equalization of economic growth rates of different countries (Mankiw G., Romer D., Weil D., 1992).

The idea of the dependence of economic growth on the quantity and quality of human capital was concretized in the models of P.Agion and P. Howitt (Aghion \& Howitt, 1992) and the research by Charles Jones (Jones, 1995), where human capital became the factor in the production of new knowledge and innovation in the Research \& Development sector, as well as in the model of technology dissemination by R. Barro and H. Sala-i-Martin (Barro \& Sala-i-Martin, 1992), which proved the possibility of faster economic growth in the countriesimitators of new technologies rather than the leading countries. Despite different preconditions and the use of different approaches to the modification of R. Solow's basic model, all these attempts to link the uneven development with the stock of physical and human capital solved the problem of backwardness in the same way: a country striving for development, has to invest faster in education and Research \& Development and make its economy more open.

Following this path, a number of underdeveloped countries began to actively increase the potential of education. Large-scale reforms in this area are characteristic of Indonesia, where 61,000 new schools have been built and $85 \%$ of children have got primary education, which has further increased the wages of every educated Indonesian by an average of $3.8 \%$ (Duflo, 1999). The same path was followed by Taiwan and South Korea, which reached a literacy rate of $98 \%$, and the level of higher education in 2003 took third place in the world after Canada and the United States, with 4540 students per 100000 population (Nureyev, 2008). In general, with the support of the World Bank, by 1990 the level of primary education in half of the world reached $100 \%$, while in 1960 only $28 \%$ of the world's children attended primary school. The same applies to university education. While in 1960 in 29 countries of the world there were no students at all, then by 1990 there were only three such countries left. The median global higher education enrollment rate increased more than sevenfold from 1 to $7.5 \%$ between 1960 and 1990 (Easterly, 2006).

However, despite such successes in increasing human capital, not all countries have managed to achieve economic 
growth at a similar pace. Thus, against the background of the educational boom, sub-Saharan African countries did not increase their GDP at all, while Singapore, Korea, China and Indonesia showed the opposite trend compared to African countries in terms of human capital growth. Japan, where the development of education was very moderate, had such a high rate of economic growth, that researchers had to call it the "Japanese miracle". This led to conclusions about the ambiguity of the impact of human capital on economic growth. Examining such contradictory trends, a number of authoritative researchers have been forced to acknowledge the lack of a direct link between the development of education and the rate of economic growth of GDP (Easterly, 2006). This served as an impetus for more in-depth research on this issue.

Focusing on the materials of the period when the so-called Asian tigers made an unprecedented leap in catching up, we came to the conclusion that human capital alone cannot be a self-sufficient factor of economic growth. Education and high qualification of the labor force as a basis for the commissioning of highly productive means of production, as well as its ability to produce new knowledge and create new technologies, requires a number of conditions. A country that relies on human capital should, above all, ensure that this capital can be appropriately utilized, which requires investment in its economy. Considering the incentives for investment, we are forced to recognize that the availability of highly skilled labor, being a necessary condition for ensuring a return on the means of production, however, is not limited to it. The investor takes into account a range of factors that affect the profitability of his business. Therefore, it is not just human capital that is important, but its compliance with the flow of physical capital that is invested in a particular economy.

If we look at the fast-growing Asian countries in the late twentieth century, we cannot ignore the fact that they were all a zone of large-scale foreign investment initiated by foreign economic aid. According to statistics of that time, Western countries actively subsidized Asian economies, seeing them as outposts against the spread of communist regimes. In the 1950s, the United States and its allies actually subsidized 40 percent of Taiwan's total imports and more than 80 percent of South Korea's imports. By the early 1960s, similar investments had financed up to $70 \%$ of all manufacturing investment in Korean industry. This figure was not much lower in Taiwan (Inozemtsev, 2000). In addition to foreign investment, the governments of these countries have also pursued policies aimed at sustaining economic growth through subsidies and lending. Thus, the educational boom in Asian economic growth leaders was supported by an investment boom which was no less powerful. This, in our opinion, was the main reason for these countries to achieve an unprecedented pace of catching up at the turn of the century.

However, speaking about the success of the catching-up development of Asian countries, it should be noted that the synchronization of human and physical capital is a necessary but not sufficient condition for ensuring a high rate of GDP growth. Qualitative parameters of these components also acquire importance. It should be noted that in the pioneering models of economic growth, which took into account human capital, the latter was calculated by taking into account the access of the population to secondary education. It is clear that this approach reflected the opportunities of purely industrial development. By relying on the combination of physical and human capital in this development, the countries we studied have indeed shown impressive successes, but began to lose their positions sharply when the developed economies of the world began to actively implement the achievements of the fourth industrial revolution. Thus, both human and physical capital must grow synchronously in terms of their quality parameters, i.e. the increase in the level of education and skills of people must be accompanied by appropriate innovative changes in the structure of physical capital.
To verify this conclusion, we analyzed the relevance of human and economic development indicators in countries which are different in living standards and show different rates of GDP growth in modern conditions. The known index of human development was used as a key indicator of human capital, and the characteristics of compliance of the state of physical capital with the innovative principles of its use - the global index of innovation $[7,8]$. As a result, we have got three clusters that brought together groups of countries with high, medium and low levels of compliance of the selected indicators (Fig. 1).

Switzerland, the USA, Sweden, the Netherlands, Britain, Germany, Denmark, Finland, France, Japan, Hong Kong, South Korea, Israel and Singapore are among the world leaders that combine a high level of human capital and innovative nature of economic development, which allows them to maintain their leadership in the ranking of countries with high human development index. 16 countries are with an average level of compliance between human development and economic innovation, including Ukraine; and the cluster with the lowest level of compliance between these indicators -6 countries, with Ethiopia occupying the last rank. China occupies an intermediate position between groups of countries with high and medium levels of correspondence between human and physical capital. Over the past decade, China, in response to rising costs of its extensive production and increasing environmental legislation, was forced to focus on building high-tech and innovative economy. The experience of China, which has managed to form the foundations for successful development in a relatively short period of time, confirms the idea of the need for synchronous growth of not only quantitative but also qualitative parameters of human and physical capital.

If we consider the specifics of the economic policy pursued by the Chinese government in order to achieve high rates of economic growth, its focus on qualitative growth and convergence of these two parameters is obvious. Indeed, recent decades have been marked for China by attracting labor and foreign direct investment through its country's position as a center of higher education, professional experience, talent, knowledge and innovation. A number of projects began to be actively implemented here, which should create centers of concentration of physical and human capital.

First of all, it was an initiative to create "smart cities" centers of concentration of science, technology and human capital. Taking into account the fact that it is the large urban agglomerations that actually are the leaders of scientific and technological progress and economic growth (only 600 cities with $1 / 5$ of the world population now generate $60 \%$ of the world's gross domestic product [9]), the Chinese government and local authorities began to actively promote the development of their cities, mainly in coastal regions, including Hong Kong and Beijing. As education contributes to the growth of innovation potential and labor productivity, an important factor in increasing the competitiveness of cities is their ability to create conditions for the education of talented youth and to retain the graduates of local higher education institutions.

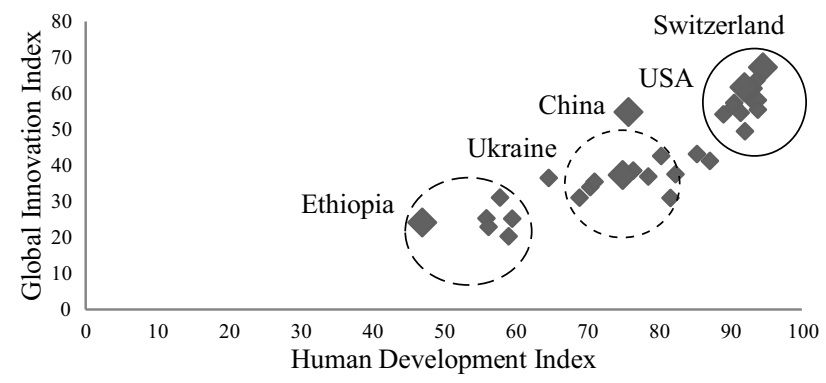

Fig. 1. Clusters of countries by compliance with the level of human development and innovation 
In order to implement the strategy of increasing the number of world-class universities within the country, the Chinese government has decided to finance the training of scientific and pedagogical staff in the world's leading universities. In just seven years of implementing such a policy, the number of state-funded state scholarships for Chinese youth to study abroad increased from 3000 in 2003 to 13000 in 2010 (British Council, DAAD, 2014). As the country with the largest number of students living abroad, China has drastically changed its policy on the mobility of scientists. Starting from 1992, the Chinese government began to encourage students who chose to live in other countries to return home and pass on their knowledge and experience to their compatriots. Since the proclamation of such a policy, China has managed to return more than 3 million students [10].

Since 2008, a similar policy has been implemented in relation to scientists, especially innovators, leaders in the development of new technologies and heads of corporations in hightech industries. Through state funding for special programs, former Chinese immigrants were provided with citizenship, free premium housing, subsidies for startups, and a special research grant, and a salary equal to that received abroad. By 2015, 4100 emigrants were accepted under such programs, which significantly increased the country's human capital ratio. Valuable "trophies" were Wang Xiaodong, a researcher at the prestigious Howard Hughes Medical Institute, one of the youngest members of the US National Academy of Sciences, and Shi Yigong, a professor of structural biology at the famous Princeton University.

At the same time, China began to actively develop the domestic market for educational services, financially supporting its higher education institutions and contributing to the growth of their image in the world. Large-scale investments in infrastructure development, equipping university laboratories with advanced equipment and creating science parks where talented students can conduct their research, along with the low cost of education itself, have quickly paid off. It is the low cost of education for both residents and foreigners, along with the high scientific and technical potential of educational institutions, that provided an increasing flow of applicants from other countries seeking to study in China. Thanks to this, it is possible to concentrate talented and creative people in the country who are able to produce scientific knowledge and innovations. Interestingly, such a concentration prevails precisely in those areas of knowledge that create the foundation for the accelerated development of scientific and technological progress. Mathematics, engineering and technology, science, information technology are the areas that students most often choose to study and in which China ranks high in the world rankings (British Council, DAAD, 2014).

According to analysts, over the past decade, Chinese universities have made a major breakthrough: today, Chinese diplomas are highly valued in the world, and the level of training is not inferior to Europe and the United States. This is confirmed by authoritative world rankings. Thus, according to QS, in 2020, six Chinese universities have entered the top 100 best universities in the world, and Tsinghua University left behind such "monsters" as Yale and Columbia Universities. The same cohort includes five Hong Kong universities. Thanks to their universities and their international student and research representation, Chinese cities, in fact, manage to increase human capital. According to the ranking of global cities, such cit-

Table 1

The growth rate of total fixed capital investment in China compared to the previous year, \% [13]

\begin{tabular}{|c|c|c|c|c|c|c|}
\hline \multirow{2}{*}{ Years } & \multirow{2}{*}{ Total } & \multicolumn{5}{|c|}{ Sources of investment } \\
\hline & & State budget & Domestic loan & Foreign investment & Internal resources of enterprises & Other resources \\
\hline 1996 & 14.1 & 1.4 & 9.0 & 19.7 & 5.2 & 58.9 \\
\hline 1997 & 8.1 & 11.3 & 4.6 & -2.3 & 12.6 & 6.5 \\
\hline 1998 & 13.7 & 71.9 & 15.9 & -2.5 & 11.6 & 17.7 \\
\hline 1999 & 3.6 & 54.7 & 3.3 & -23.3 & 4.4 & 3.5 \\
\hline 2000 & 11.3 & 13.9 & 17.5 & -15.5 & 11.5 & 13.2 \\
\hline 2001 & 14.7 & 20.7 & 7.6 & 2.0 & 15.9 & 20.7 \\
\hline 2002 & 18.6 & 24.1 & 22.4 & 20.5 & 20.6 & 7.5 \\
\hline 2003 & 30.1 & -15.0 & 36.0 & 24.7 & 37.8 & 21.0 \\
\hline 2004 & 27.2 & 21.1 & 14.5 & 26.4 & 31.2 & 31.8 \\
\hline 2005 & 26.9 & 27.6 & 18.4 & 21.1 & 33.5 & 16.0 \\
\hline 2006 & 25.8 & 12.5 & 20.0 & 8.9 & 29.0 & 28.3 \\
\hline 2007 & 26.8 & 25.4 & 17.6 & 18.4 & 28.6 & 31.7 \\
\hline 2008 & 21.3 & 35.8 & 14.8 & 3.5 & 29.7 & -2.8 \\
\hline 2009 & 36.8 & 59.5 & 48.6 & -13.0 & 29.5 & 62.4 \\
\hline 2010 & 24.3 & 15.7 & 20.2 & 7.9 & 28.4 & 17.1 \\
\hline 2011 & 21.1 & 14.1 & 5.3 & 7.6 & 28.3 & 11.2 \\
\hline 2012 & 18.4 & 27.7 & 11.3 & -11.7 & 21.1 & 12.9 \\
\hline 2013 & 20.0 & 17.7 & 15.2 & -3.3 & 20.3 & 25.3 \\
\hline 2014 & 10.6 & 19.9 & 9.7 & -6.2 & 13.6 & -5.0 \\
\hline 2015 & 7.5 & 15.6 & -6.4 & -29.6 & 9.2 & 10.1 \\
\hline 2016 & 5.6 & 17.1 & 10.1 & -20.5 & -0.2 & 30.7 \\
\hline 2017 & 3.6 & 7.0 & 7.8 & -5.5 & 0.9 & 11.2 \\
\hline 2018 & 3.2 & 0.1 & -6.1 & -2.7 & 3.9 & 8.0 \\
\hline
\end{tabular}


ies as Beijing and Shanghai are consistently in the top 10 in attracting global capital, people and ideas [12]. The creation of favorable conditions for increasing human capital has yielded results in the field of attracting foreign capital.

As can be seen from Table 1, the largest growth rates of foreign investment in the Chinese economy date back to 2000, when large-scale public investment in human capital in the 1990s began to yield the first results. In absolute terms, China accounted for an average of $6-7 \%$ of world foreign direct investment, which was higher than in most European countries and the United States. If at the beginning of the "open door" policy, China attracted foreign investors with cheap labor, then after the implementation of projects for the development of education and science, the knowledge and technology generated by the Chinese scientific community stimulated the world's leading companies to approach them. During this period, 490 of the world's 500 largest TNCs invested in the Chinese economy and set up 1,200 research and development centers there, which contributed to the technical development of local enterprises. Today, we are witnessing the presence in China of such powerful US corporations as General Motors, Westinghouse electric, IBM, Sykorsky, Hewlett-Packard and others, not to mention the numerous branches of Japanese and European industrial companies. Universities and research institutions with unique innovation infrastructure, high-level scientists, accumulated knowledge and technological experience, as well as highly qualified specialists who are able to quickly solve the problems of companies in their region, significantly increased their competitive position in attracting investment projects. This is evidenced by the data in Table 2 .

If we analyze the forms in which foreign investment in China was made directly, the fact of the dominance of joint ventures becomes obvious. They received priority state support as they provided for the deep integration of the foreign party into production and its higher interest. Starting from the 2000s, the government began inviting the Chinese diaspora to contribute to the modernization of the country without any obligation to return to China (Zweig, et al., 2008). According to statistics, about $70 \%$ of foreign direct investment in this period accounted for Huaqiao - the Chinese living in other countries. It was these investors who had strong ties in mainland China, well aware of the traditions and rules of doing business in this country. The ethnic nature of investment in the Chinese economy has made it possible in a relatively short period of time to achieve a high return on investment, and subsequently to ensure a large-scale expansion of the Chinese capital in the world. According to researchers, today Chinese investors are actively seeking access to a business that has unique technologies, well-established sales channels and wellknown brands. The most well-known acquisitions of foreign companies by Chinese investors include a significant part of the production of the French TV company Thomson, the purchase of Lenovo's laptop division at the world-famous IBM and Motorola Mobility from Google, and the acquisition of Korean manufacturer Ssangyong Motor by the automotive industry Shanghai Automotive Industry Corporation, as well as the acquisition of Volvo by Geely Automobile, a Chinese private company [14].

These examples show not only the success of the Chinese economy in achieving the current goals of its development, but also the formation of an appropriate socio-economic basis for a fully competitive position in world markets in the mid- and long-term perspective. This is evidenced by the results of the assessment of the state of production facilities and opportunities for their development for 100 countries, which are contained in the report of the World Economic Forum "Readiness for the future of production". This assessment was based on many indicators combined into two key groups - "Struc-

Table 2

The volume of $R \& D$ and patents of industrial enterprises in China [13]

\begin{tabular}{|c|c|c|c|c|c|c|}
\hline Registration status & $\begin{array}{l}\text { Number of } \\
\text { R\&D staff }\end{array}$ & $\begin{array}{c}\text { Expenses on } \\
\text { R\&D (mln Yuan) }\end{array}$ & $\begin{array}{c}\text { Number of } \\
\text { R\&D projects }\end{array}$ & $\begin{array}{c}\text { Number of patent } \\
\text { applications }\end{array}$ & $\begin{array}{l}\text { Including } \\
\text { inventions }\end{array}$ & $\begin{array}{c}\text { Number of valid } \\
\text { patents for inventions }\end{array}$ \\
\hline Total & 2981234 & 1295482.64 & 472299 & 957298 & 371569 & 1094200 \\
\hline Medium and large enterprises & 2016465 & 954269.47 & 213215 & 541149 & 241854 & 692288 \\
\hline Domestic enterprises & 2327232 & 1027204.72 & 395457 & 819575 & 321873 & 907856 \\
\hline State & 21624 & 8343.78 & 2632 & 10004 & 4771 & 12259 \\
\hline Collective & 2126 & 778.89 & 336 & 373 & 147 & 340 \\
\hline Cooperative & 2175 & 699.43 & 591 & 617 & 133 & 553 \\
\hline Partnership & 108 & 28.99 & 28 & 32 & 17 & 36 \\
\hline LLC & 862665 & 427933.43 & 125602 & 277326 & 126831 & 365468 \\
\hline Corporations & 125482 & 71074.16 & 17052 & 50873 & 23494 & 57907 \\
\hline Private & 993467 & 385161.19 & 208855 & 380281 & 122242 & 322578 \\
\hline Other & 2368 & 1741.57 & 235 & 262 & 111 & 619 \\
\hline $\begin{array}{l}\text { Enterprises of Hong Kong, } \\
\text { Makau and Taiwan }\end{array}$ & 319641 & 113075.0 & 36250 & 68851 & 25946 & 89280 \\
\hline Partnerships & 107096 & 41180.14 & 14127 & 24945 & 9070 & 33172 \\
\hline Cooperatives & 3130 & 1124.52 & 434 & 498 & 131 & 430 \\
\hline Private & 182142 & 60905.16 & 19336 & 38234 & 14420 & 48713 \\
\hline JSC & 25275 & 9011.97 & 1966 & 4805 & 2263 & 6642 \\
\hline Foreign enterprises & 334362 & 155202.92 & 40592 & 68872 & 23750 & 97064 \\
\hline Partnerships & 142701 & 82212.04 & 18115 & 35122 & 11844 & 44918 \\
\hline Cooperatives & 3653 & 1647.74 & 621 & 842 & 293 & 850 \\
\hline Private & 166758 & 61777.1 & 19461 & 27371 & 9215 & 42674 \\
\hline JSC & 17203 & 8420.15 & 1986 & 4820 & 2150 & 7997 \\
\hline
\end{tabular}




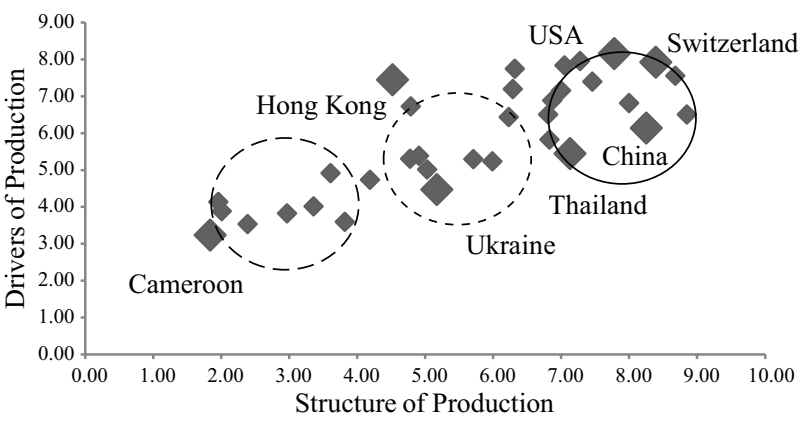

Fig. 2. Clusters of countries in terms of compliance with the level of production structure and drivers of economic development

ture of production", an important component of which is the quality of human capital, and "Drivers of production", which primarily characterize the technological readiness of countries to meet the challenges of the fourth industrial revolution [15]. Using the results of this study for the group of countries considered earlier, we identified clusters of countries in terms of compliance with the level of their production structure and existing drivers of economic development (Fig. 2).

As this figure shows, China's economy, along with other leading countries in the world, is the best prepared for future progressive economic development and is one of the most competitive in the context of the fourth industrial revolution. As for Ukraine, neither its existing production structure nor its potential for technological renewal is sufficient to meet the future requirements of the world's socio-economic development.

Conclusions. Traditionally, the inability of developing countries to achieve high rates of economic growth is associated with low levels of their human capital. New empirical data, used to test the most well-known models of economic growth with this factor in mind (Romer, Lucas, Barro, and Sala-i-Martin, Agion, and Howit models), did not reveal a direct link between economic growth and investment in human capital. Analysis of the world experience of successful implementation of the concept of catching up development through human capital growth in a number of Asian countries has shown that human capital becomes a powerful factor of economic growth only if there is appropriate investment in physical capital. However, such dependence was valid in the conditions of the industrial mode of production, and does not occur at the stage of post-industrial development.

For the successful realization of the potential of human capital in the modern conditions of mastering the achievements of the fourth industrial revolution, the main condition must be the conformity of its qualitative characteristics to the technical and technological characteristics of physical capital and, above all, its potential to innovate. Based on the comparison, firstly, of indicators of the level of human development and innovation and, secondly, indicators of production structure and drivers of production, the dependence of economic growth rates on the synchronization of quantitative and qualitative characteristics of human and physical capital is established.

\section{References.}

1. Mormina, M. (2019). Science, Technology and Innovation as Social Goods for Development: Rethinking Research Capacity Building from Sen's Capabilities Approach. Sci Eng Ethics, 25, 671-692. https://doi.org/10.1007/s11948-0180037-113.

2. Bezuidenhout, L., Leonelli, S., Kelly, A., \& Rappert, B. (2017). Beyond the digital divide: Towards a situated approach to open data. Science and Public Policy, 44(4), 464-475. https://doi.org/10.1093/scipol/scw036.

3. Bezuidenhout, L., \& Chanakya, E. (2018). Hidden concerns of sharing research data by low/middle income country scientists. Global Bioethics, 29(1), 39-54. https://doi.org/10.10 80/11287462.2018.1441780.

4. Martineza, W. (2018). How science and technology developments impact employment and education. PNAS, 115(50). https://doi.org/10.1073/pnas.1803216115.

5. Salikhova, O., \& Bak, H. (2014). Strategies of Asian countries to develop national industry through the involvement of TNC technologies. Foreign trade: economics, finance, law, 3(74), 30-40.

6. Pylypenko, H., Fedorova, N., Hyzenko, I., \& Naumenko, N. (2020). Paradoxes of Economic Development: Science and Innovation in the Modern World. Naukovyi Visnyk Natsionalnoho Hirnychoho Universytetu, (2), 153-159. https://doi. org/10.33271/nvngu/2020-2/153.

7. Global Innovation Index 2019(2019). Retrieved from https:// www.wipo.int/publications/en/details.jsp?id=4434.

8. Report on human development 2019 (2019). Retrieved from http://hdr.undp.org/sites/default/files/hdr_2019_overview - russian.pdf.

9. UNESDOC (2016). Education for people and planet: creating sustainable futures for all, Global education monitoring report, 2016. Retrieved from https://unesdoc.unesco.org/ark:/48223/ pf0000245752 rus.

10. UNESDOC (2016). UNESCO science report: towards 2030. Retrieved from https://unesdoc.unesco.org/ark:/48223/ pf0000235406 rus.

11. World University ranking, 2020 (2020). Retrieved from https://www.topuniversities.com/university-rankings/worlduniversity-rankings/2020.

12. Kearney, A. T. (2019). Global Cities report. Retrieved from https://www.kearney.com/global-cities/2019.

13. Statistical Yearbook of the Republic of China (2019). Retrieved from http://www.stats.gov.cn/tjsj/ndsj/2019/indexeh. htm.

14. Shelukhin, A. (2016). Peculiarities of the activities of transnational corporations in China on mergers and acquisitions. Problems of Modern Economics, (3), 86-89.

15. Readiness for the Future of Production Report (2018). Retrieved from http://www3.weforum.org/docs/FOP Readiness_Report_2018.pdf.

\section{Взаємозв'язок людського капіталу та інновацій у контексті техніко- технологічного розвитку країн світу}

\section{Ю. В. Дубєй}

Національний технічний університет «Дніпровська політехніка, м. Дніпро, Україна, e-mail: yuliya.dubey@gmail.com

Мета. Виявлення взаємозв'язку між економічним зростанням країн і ключовими детермінантами технікотехнологічного розвитку.

Методика. У ході дослідження були використані такі загальнонаукові методи наукового пізнання, як: факторний аналіз - для виокремлення ключових чинників економічного зростання; метод логічного та історичного аналізу - для виявлення специфіки Азійських країн як лідерів наздоганяючого розвитку; статистичні методи для встановлення залежності темпів економічного зростання країн від кількісних і кісних характеристик людського й фізичного капіталів.

Результати. Проаналізовані моделі економічного зростання, базовані на використанні людського капіталу як фактору нарощування ВВП. На фактичному матеріалі про результати економічного розвитку країн, що у 90-ті рр. ХХ ст. активно проводили реформи у сфері освіти, доведена відсутність прямого зв'язку між інвестиціями в людський капітал і економічним зростанням. Виокремлені передумови для успішної реалізації потенціалу 
людського капіталу, головною з яких визнана відповідність його якісних характеристик техніко-технологічним характеристикам фізичного капіталу. На вибірці із 36 країн світу доведена дана залежність і виокремлені кластери країн за відповідністю показників людського розвитку та інноваційності економік, а також структури їх виробництва та існуючих драйверів розвитку. На прикладі Китаю продемонстрована успішна імплементація політики нарощування потенціалу людського капіталу 3 відповідними технологічними зрушеннями на основі надання інвестиціям інноваційної спрямованості.

Наукова новизна. Доведена залежність темпів економічного зростання від синхронізації кількісних і якісних характеристик людського й фізичного капіталів, обгрунтовані необхідні й достатні умови для виходу країни на траєкторію сталого техніко-технологічного розвитку.

Практична значимість. Встановлений взаємозв'язок між економічним зростанням країн і відповідністю між собою кількісних і якісних характеристик людського й фізичного капіталів дозволяє більш ефективно обирати напрями економічної політики держави у сфері технікотехнологічного розвитку.

Ключові слова: науково-технічний розвиток, моделі економічного зростання, людський капітал, інновації, темпи зростання ВВП

\section{Взаимосвязь человеческого капитала и инноваций в контексте технико- технологического развития стран мира}

\section{Ю. В. Дубей}

Национальный технический университет «Днепровская политехника», г. Днепр, Украина, e-mail: yuliya.dubey@ gmail.com

Цель. Выявление взаимосвязи между экономическим ростом стран и ключевыми детерминантами техникотехнологического развития.

Методика. В ходе исследования были использованы следующие общенаучные методы научного познания: факторный анализ - для выделения ключевых факторов экономического роста; метод логического и исторического анализа - для выявления специфики Азиатских стран как лидеров догоняющего развития; статистические методы - для установления зависимости темпов экономического роста стран от количественных и качественных характеристик человеческого и физического капитала.

Результаты. Проанализированы модели экономического роста, основанные на использовании человеческого капитала как фактора наращивания ВВП. На фактическом материале о результатах экономического развития стран, которые в 90-е гг. XX в. активно проводили реформы в сфере образования, доказано отсутствие прямой связи между инвестициями в человеческий капитал и экономическим ростом. Выделены предпосылки для успешной реализации потенциала человеческого капитала, главным из которых признано соответствие его качественных характеристик технико-технологическим характеристикам физического капитала. На выборке из 36 стран мира доказана данная зависимость и выделены кластеры стран за соответствием показателей человеческого развития и инновационности экономик, а также структуры их производства и существующих драйверов развития. На примере Китая продемонстрирована успешная имплементация политики наращивания потенциала человеческого капитала с соответствующими технологическими сдвигами на основе придания инвестициям инновационной направленности.

Научная новизна. Доказана зависимость темпов экономического роста от синхронизации количественных и качественных характеристик человеческого и физического капитала, обоснованы необходимые и достаточные условия для выхода страны на траекторию устойчивого технико-технологического развития.

Практическая значимость. Установленная взаимосвязь между экономическим ростом стран и соответствием между количественными и качественными характеристиками человеческого и физического капитала позволяет более эффективно выбирать направления экономической политики государства в сфере технико-технологического развития.

Ключевые слова: научно-техническое развитие, модели экономического роста, человеческий капитал, инновации, темпы роста ВВП

Recommended for publication by V.Ya. Shvets, Doctor of Economic Sciences. The manuscript was submitted 28.05.20. 